\title{
Unusual association of emphysematous cystitis and chronic alcoholism
}

\author{
Aasems Jacob, ${ }^{1}$ Sayee Sundar Alagusundaramoorthy, ${ }^{1}$ Isha Verma, ${ }^{1}$ Durga Bodala ${ }^{2}$
}

${ }^{1}$ Department of Internal Medicine, Monmouth Medical Center, Long Branch, New Jersey, USA

${ }^{2}$ Monmouth Medical Center, Long Branch, New Jersey, USA

\section{Correspondence to} Dr Aasems Jacob, aasemsj@gmail.com

Accepted 3 March 2017

\section{CrossMark}

To cite: Jacob $A$, Alagusundaramoorthy SS, Verma I, et al. BMJ Case Rep Published online: [please include Day Month Year] doi:10.1136/bcr-2017219594

\section{DESCRIPTION}

A Caucasian woman aged 65 years with a history of chronic alcoholism presented to the hospital with confusion. Abdominal examination revealed lower abdominal tenderness with no guarding or rigidity. Ethanol level was $378 \mathrm{mg} / \mathrm{dL}(<10 \mathrm{mg} / \mathrm{dL}$ : absent; $>300 \mathrm{mg} / \mathrm{dL}$ : potentially fatal level) and blood counts in low normal range. Lactic acid was elevated to $3.6 \mathrm{mmol} / \mathrm{L}$ and urinalysis revealed pyuria, haematuria, 4+bacteria and positive leucocyte esterase. CT scan of the abdomen showed air within the bladder wall without urinary calculus or obstruction (figures 1 and 2). Patient's mental status improved with intravenous hydration and ertapenem. Urine culture showed heavy growth of levofloxacin-sensitive Escherichia coli and the antibiotic was narrowed down. Abdominal ultrasound scan performed after 14 days showed resolution of free air in bladder walls.

Emphysematous urinary tract infection is characterised by air within the lumen and walls of the urinary tract. ${ }^{1}{ }^{2}$ Escherichia coli and Klebsiella infections in patients with diabetes, old age, urinary catheter insertion and immunosuppression may lead to emphysematous cystitis. Abdominal pain, fever, haematuria and pyuria are the common presenting symptoms. Delayed treatment can result

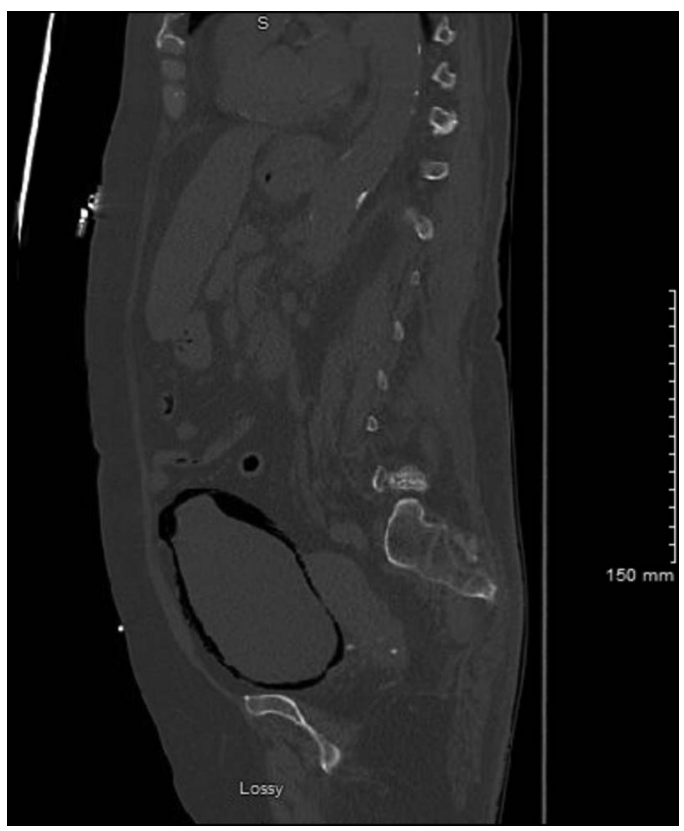

Figure 1 Sagittal CT image of the abdomen showing free air in bladder walls diagnosed as emphysematous cystitis.

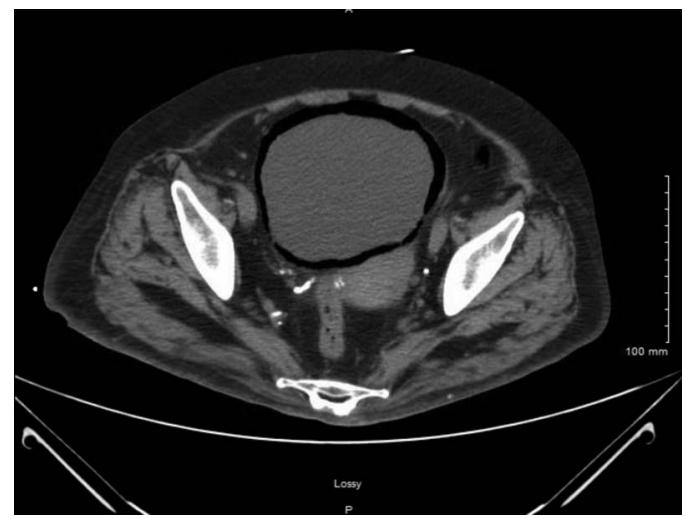

Figure 2 Axial CT image of the abdomen of the same patient showing free air in bladder walls.

in complications like fistula, bladder rupture, sepsis and even death. Diagnostic modality of choice is CT of the abdomen, and is advised to be used in patients with high suspicion for the condition to minimise complications. Our patient possibly had immunosuppression from alcohol use which has been well documented in the literature. ${ }^{3}$ The classical risk factors like diabetes, anatomical abnormality on imaging or any recent gynaecological/ urological procedures were absent. Acute and chronic alcoholism can mask the signs and symptoms of infection by its dose-dependent negative effect on adaptive and innate immunity. ${ }^{4}$ Its effect on leucocytes manifests with low cell counts as well as decreased function leading to impaired cytokine production. $^{5}$

\section{Learning points}

- Elderly, diabetic and immunosuppressed patients and those with recent urinary catheter insertion or urological procedures are at high risk of developing emphysematous cystitis.

- Early diagnosis with CT abdomen and treatment can prevent complications like fistula, bladder rupture or extension of infection.

- Alcohol can mask the common signs and symptoms of infection as well as affect the inflammatory markers and chronic alcoholics should be considered at high risk of life-threatening infections due to immunosuppression and appropriate antimicrobials should be instituted promptly. 
Contributors AJ is responsible for planning, preparation of manuscript including conception, review of literature and submission. SSA is responsible for patient care, initial planning, reporting, acquisition of clinical history and review of literature. IV is responsible for patient care, planning and conception of the case report, and acquisition of images. DB is responsible for patient care,

supervision of the planning and preparation of manuscript, reviewing the report and editing.

Competing interests None declared.

Patient consent Obtained.

Provenance and peer review Not commissioned; externally peer reviewed.

\section{REFERENCES}

1 Thomas AA, Lane BR, Thomas AZ, et al. Emphysematous cystitis: a review of 135 cases. BJU Int 2007;100:17.

2 Huang JJ, Tseng CC. Emphysematous pyelonephritis: clinicoradiological classification, management, prognosis, and pathogenesis. Arch Intern Med 2000;160:797.

3 Cook RT. Alcohol abuse, alcoholism, and damage to the immune system - a review. Alcohol Clin Exp Res 1998;22:1927-42.

4 Barr T, Helms C, Grant K, et al. Opposing effects of alcohol on the immune system. Prog Neuropsychopharmacol Biol Psychiatry 2016;65:242-51.

5 Gacouin A, Roussel M, Gros A, et al. Chronic alcohol exposure, infection, extended circulating white blood cells differentiated by flow cytometry and neutrophil CD64 expression: a prospective, descriptive study of critically ill medical patients. Ann Intensive Care 2012;2:50.

Copyright 2017 BMJ Publishing Group. All rights reserved. For permission to reuse any of this content visit http://group.bmj.com/group/rights-licensing/permissions.

BMJ Case Report Fellows may re-use this article for personal use and teaching without any further permission.

Become a Fellow of BMJ Case Reports today and you can:

- Submit as many cases as you like

- Enjoy fast sympathetic peer review and rapid publication of accepted articles

- Access all the published articles

- Re-use any of the published material for personal use and teaching without further permission

For information on Institutional Fellowships contact consortiasales@bmjgroup.com

Visit casereports.bmj.com for more articles like this and to become a Fellow 